\title{
ENDEMIC DISREGARD FOR THE INTERNATIONAL RULE OF LAW IN AFRICA?
}

\author{
Marek Jan Wasinski*
}

\section{Introduction}

An African attitude towards the protection of human rights has been labelled bluntly as 'rooted in endemic disregard for the rule of law as such $^{1}$ so often that this intellectual cliché more and more often effectively discourages attempts to oppose or disprove such a statement. However, scientific honesty requires a special prudence in dealing with a commonplace such as that. Hence, this paper offers a brief survey, essentially neither to definitely confirm nor to falsify the abovementioned thesis but to tackle a selected problem related thereto. Instead of a common high-altitude and high-speed study based on a sketchy and general observations regarding numerous African legal instruments and accompanied practice, this paper presents an analysis of a selected phenomenon (one which provoked caustic comment) to distil more general observations.

* PhD, LLM, Assistant Professor, Faculty of Law and Administration, University of Lodz, Poland; marek.wasinski@gmail.com.

1 E. de Wet, The Rise and Fall of the Tribunal of the Southern African Development Community: Implications for Dispute Settlement in Southern Africa, 'ICSID Review' 2013, vol. 28, p. 62. 
In a nutshell, the case concerns land reform in Zimbabwe involving the compulsory acquisition of property, ${ }^{2}$ which was subsequently held to be incompatible with the Treaty of the Southern African Development Community (SADCT) ${ }^{3}$ by the Tribunal of the SADC (SADC Tribunal) in 2008. The malevolent attitude of the SADC's political organ (SADC Summit) and the SADC's member states towards the judgment, not only legitimized de facto Zimbabwean non-compliance policy and contempt of the SADC Tribunal but also culminated in an odd (prima facie at least) suspension of the judicial body by the SADC Summit. ${ }^{5}$ This, in turn, has led to the initiation of two international legal proceedings challenging the decision of the SADC Summit: before the African Commission on Human and Peoples' Rights (African Commission) ${ }^{6}$ and before the African Court on Human and Peoples' Rights ${ }^{7}$ (African Court) - both of which remain pending.

Having myself visited Windhoek, Namibia on one crisp winter morning in July 2013, I found the neo-classicist Turnhalle building, the seat of the SADC Tribunal, charmingly embellishing a typical European-like urban corner of Banhoff Street and (ominously enough) Robert Mugabe Avenue. It was as dormant as a deserted film set, with a few pale information leaflets in a library and swivel chairs in a courtroom carelessly left behind the bench as if the building had been left in a rush. In fact, nothing here resembled the gloomy burrow of 'a monster created to devour us all' as Tanzania's President Kikwete had qualified the SADC Tribunal in a Gandalf-styled

2 GJ Naldi, Mike Campbell (Pvt) Ltd et al $v$ The Republic of Zimbabwe: Zimbabwe's Land Reform Programme Held in Breach of the SADC Treaty, 'Journal of African Law' 2009, vol. 53, pp. 307-310.

3 Treaty of the Southern African Development Community, Windhoek, 17.8.1992.

4 Mike Campbell (Pvt) Ltd. \& Others v The Republic of Zimbabwe (Campbell Case) (2008) SADC Tribunal 2 (28.11.2008).

5 'Communique of the 30th Jubilee Summit of SADC Heads of State and Government' (20.8.2010); 'Communiqué Extraordinary Summit Heads Of State and Government of the Southern Africa Development Community' (20.5.2011); 'Final Communiqué of the 32nd Summit of SADC Heads of State and Government' (18.8.2012). See also: F Cowell, The Death of the Southern African Development Community Tribunal's Human Rights Jurisdiction, 'Human Rights Law Review' 2013, vol. 13, p. 153-165.

${ }^{6}$ Notice of Communication of 22.7.2011. On 16.11.2012 African Commission declared communication admissible, Communication $\mathrm{nr}$ 409/12, Letter of Communication of 16.11.2012, Ref. ACHPR/COMM/409/12/0.5/1115/12, unpublished.

7 Request for Advisory Opinion of 23.11.2012. 
harangue. ${ }^{8}$ And nothing remained to convince the observer that this was definitely the seat of a judicial organ that uncompromisingly fulfilled its mandate or, conversely, that recklessly exceeded the competences it had been granted. Instead, one was left with the impression that the SADC Tribunal was simply doomed to failure merely in order to fuel academic debates on the rule of law and human rights protection in Africa. After all, the present paper is likewise provoked by the fate of the SADC Tribunal and the accompanying bitter doctrinal appraisal. Its fortune merely anchors one key issue to be discussed more thoroughly: was it reasonable to conclude that the SADC Tribunal had been dismantled solely as a result of an endemic disregard for the rule of law?

\section{The rule of law - in search of meaning}

Therefore, to begin with some basics: what are the normative parameters of the rule of law? Does it have an autonomous legal content capable of creating precise legal rights and obligations? Or is it merely one of those political or essay baubles employed without inhibitions, merely to mark their context as positive, legal, trustworthy, justified etc.? Or - taking a middle path - is it a general term embracing a cluster of more precisely defined and established rules and ideas? If the first or the third conception applies: does it have only universally accepted tenets or is it amenable to regionalization in one form or another, for example as 'African rule of law'? What does the rule of law actually mean at a time when it has become a favourite catchword in political jargon, celebrated by persons holding such different views and intellectual backgrounds as Chinese, Iran, Russian, United States, Zimbabwean presidents and one mighty Afghan warlord? ${ }^{9}$ Is its meaning limited to signifying 'Hooray for Our Side'? ${ }^{10}$ A generous dose of confusion is being added as this political cacophony is entangled with lofty invocations of the rule of law in domestic constitutions, ${ }^{11}$ a celebrated

8 http://www.economist.com/blogs/baobab/2012/08/sadc-summit (accessed 30.11.2013).

9 B.Z. Tamanaha, On the Rule of Law. History, Politics, Theory, Cambridge 2004, p. 2-3.

10 T. Bingham, The Rule of Law, London 2011, p. 5.

11 Eg the Constitution of the Republic of Poland of 2nd April, 1997, Polish OJ 1997, No 78, Item 483, http://www.sejm.gov.pl/prawo/konst/angielski/kon1.htm (accessed 
preamble to the Universal Declaration of Human Rights, ${ }^{12}$ numerous resolutions of the United Nations (UN) Security Council, ${ }^{13}$ the Declaration of Principles of International Law ${ }^{14}$ or the Millennium Declaration of the UN General Assembly, ${ }^{15}$ preambles to treaties canvassed by their dispositive provisions, ${ }^{16}$ judicial decisions of both domestic ${ }^{17}$ and international courts ${ }^{18}$ or attempts to harness the rule of law as an indicator of good governance ${ }^{19}$ etc. Such heterogeneous references to the rule of law, in turn, lure academia to formulate all-compassionate learned syntheses merely to distil something more scientific than a self-evident common denominator of the state of affairs in which a legal system is in a good shape. ${ }^{20}$ Thus a great number of doctrinal output heralds how the rule of law is relocated ${ }^{21}$, sieged, ${ }^{22}$ misruled, ${ }^{23}$ recrafted ${ }^{24}$ or objectified. ${ }^{25}$ Winding-up the scientific achievements of authors, it also effectively creates an impression of being a highly imprecise and extremely complex notion, hardly susceptible to a simple and handy definition or description. For a scrupulous reader of voluminous academic writings, a theory of the rule of law may appear as a sort of a legal or social science counterpart of Einstein's theories of relativity, since they are all brutally discouraging for zealous but unprepared minds with their

\subsubsection{3).}

12 'human rights should be protected by the rule of law', A/RES/217(III) A.

13 Possibly the earliest such document is S/RES/1674 (2006) on protection of civilians during armed conflicts.

$14 \mathrm{~A} / \mathrm{RES} / 25 / 2625$.

$15 \mathrm{~A} / \mathrm{RES} / 55 / 2$.

16 Statute of the Council of Europe, London, 5.5.1949, see a preamble thereto and art 3 respectively.

$17 R v$ Secretary of State for the Home Department, Ex Parte Pierson UK House of Lords (24.7.1997) (1997) 3 The All England Law Reports.

18 Othman (Abu Qatada) v the United Kingdom ECHR (17.1.2012) 55 EHRR 1.

19 D Kaufmann et al., 'The Worldwide Governance Indicators. Methodology and Analytical Issues' No. 5430 Policy Research Working Paper.

20 J. Finnis, Natural Law and Natural Rights, Oxford 2011, p. 270. Finnis, naturally, does not perceive this phrase as resolving the problem lock, stock and barrel, see 271 et seq.

21 G. Palombella \& N. Walker (eds), Relocating the Rule of Law, Oxford 2009.

22 W.E. Scheuerman (ed), The Rule of Law under Siege. Selected Essays of Franz L. Neumann and Otto Kirchheimer, Berkely 1996.

23 E. Scarry, Rule of Law, Misrule of Man, Cambridge MA 2010.

24 D. Dyzenhaus (ed), Recrafting the Rule of Law: The Limits of Legal Order, Oxford 1999.

${ }^{25}$ M.H. Kramer, Objectivity and the Rule of Law, Cambridge 2007. 
convolutions. In fact, uncertainty still remains about what the essence of the rule of law actually is. ${ }^{26}$ Raz warned then consciously: ${ }^{27}$

[w] hen a political ideal captures the imagination of large numbers of people its name becomes a slogan used by supporters of ideals which bear little or no relation to the one it originally designated. (...) If the rule of law is the rule of the good law then to explain its nature is to propound a complete social philosophy. But if so the term lacks any useful function. We have no need to be converted to the rule of law just in order to discover that to believe in it is to believe that good should triumph. (...) Given the promiscuous use made in recent years of the expression 'the rule of law' it is hardly surprising that my claim will alarm many. We have reached the stage in which no purist can claim that truth is on his side and blame the others for distorting the notion of the rule of law.

General endorsement for the rule of law (be it declarative only) is symptomatic and clearly supports an assumption that we deal with a kind of a legal, political and sociological idea to be pursued in a given society (whether state-based or international). This is sometimes traced back to Aristotle by those who used to begin the story of the Trojan War from the egg. ${ }^{28}$ Indeed, while considering absolute monarchy, the Philosopher noted briefly and generally that it is more proper that law should govern than any one of the citizens (...) for passion influences those who are in power, even the very best of men: for which reason law is reason without desire.'. 29 This tribute to law-as-reason-rule orientated approach is inevitably grounded in the philosophical and social milieu of the fourth century $\mathrm{BC}^{30}$ and at best distantly resonates in the first most influential modern pronouncement by Dicey. As a Professor of English Law at Oxford, more than 2,000 years after the Stagirite, Dicey argued in favour of a three-dimensional character of the rule of law, perceived as 'rule, supremacy and predominance of law' or 'security given under the English Constitution to the rights of individuals'. They were named as: the absence of arbitrary power on the part of the government, subverting every man to ordinary

T. Carothers, Promoting the Rule of Law Abroad. The Problem of Knowledge, 2003 Carnegie Endowment for International Peace Working Papers, p. 3.

27 J. Raz, The Authority of Law. Essays on Law and Morality, Oxford 1979, p. 210-211.

28 Tamanaha (n 9 above) 7 et seq.

${ }_{29}$ Aristotle, A Treatise on Government, transl. W Ellis, London 1912, Book III, 1287a.

30 J.N. Shklar, Political Thought and Political Thinkers, Chicago and London 1998, p. 21-23. 
law administered by ordinary tribunals, and generating general constitutional rules by common law. ${ }^{31}$ The statement singled out and celebrated only selected features canvassing one particular domestic legal system. Nevertheless it immediately fuelled a nearly-universal drive to list the qualities of good governance. Modern formulations of the rule of law vary from thinner to thicker versions, segregated by the number and character of components involved. These components are (beginning with 'thin', that is to say the formal and most fundamental elements, and followed by the relatively less advanced 'thick' or substantial or content-related elements): rule by law - embodying law (in fact: any law) as an instrument of government in action; the formal legality of general, prospective, clear and certain law; democracy as a demanded environment and source of law; individual rights protected by the law; the protection of human dignity and human rights; social warfare. ${ }^{32}$ They form a bundle or reservoir of political and legal postulates with different volume of theoretical and practical acceptance. But they may also be used - all or some of them, like toy-bricks in various arrangements - in purely normative stipulations within the realms of both domestic and international law. Within the former, they may appear substantiated as constitutional principles, enforceable before domestic courts $^{33}$ or simply implemented through internationally stimulated processes of law-shaping ${ }^{34}$ or peace-building ${ }^{35}$ (thus justifying claims to separate the internationalized rule of law). ${ }^{36}$ For the UN-inspired assistance

31 A.V. Dicey, Introduction to the Study of the Law of the Constitution, London 1915, p. $179-180,183,189,191$. It was clearly a groundbreaking piece of writing as - according to some present-day editorials - only a year after its publication, W. Gladstone was reading it aloud in the House of Commons, citing it as authority.

32 Tamanaha (n 9 above) 91 et seq.

33 E.g. note 17 above.

34 E.g. a powerful stipulation of Art 14 of the International Covenant on Civil and Political Rights (ICCPR) or, in a more nuanced option, UN Commission on International Trade Law efforts to assist states with the drafting of national legislation on international commercial law matters, in compliance with the definition of the rule of law set out by the Secretary-General, where laws must be publicly promulgated, equally enforced and independently adjudicated and consistent with international human rights norms and standards, see: 'Guidance Note of the Secretary-General. UN Approach to the Rule of Law’ (April 2008).

35 J. Voorhoeve, From War to the Rule of Law. Peacebuilding after violent conflicts, Amsterdam 2007.

36 A. Nollkaemper, The Internationalized Rule of Law, 'Hague Journal on the Rule of Law' 2009, vol. 1, pp. 74-78. 
actions, aimed at impregnating domestic legal systems with the rule of law, the idea is defined as a principle of governance in which all persons, institutions and entities, public and private, including the state itself, are accountable to laws that are publicly promulgated, equally enforced and independently adjudicated, and which are consistent with international human rights norms and standards. It requires guarantees to ensure adherence to the principles of supremacy of the law, equality before the law, accountability to the law, fairness in the application of the law, separation of powers, participation in decision-making, legal certainty, avoidance of arbitrariness, and procedural and legal transparency. ${ }^{37}$ On the other hand, within the international society governed by international law, those 'bricks' (all or some of them) either remain veiled under a vague rule of law 'brand' found in agreements ${ }^{38}$ or they appear in the flesh in some binding $^{39}$ and non-binding documents. A Report of the Secretary-General on Strengthening and Coordinating UN Rule of Law Activities ${ }^{40}$ proclaims that

[a]t the international level, the rule of law accords predictability and legitimacy to the actions of States, strengthens their sovereign equality and underpins the responsibility of a State to all individuals within its territory and subject to its jurisdiction. Full implementation of the obligations set forth in the Charter of the United Nations and in other international instruments, including the international human rights framework, is central to collective efforts to maintain international peace and security, effectively address emerging threats and ensure accountability for international crimes.

It is quite clear, therefore, that the international dimension of the rule of law significantly differs from the domestic dimension due to certain crucial structural disparities between both legal orders. In particular, the kernel of the concept in the former is shifted from the formal qualities

37 Guidance Note of the Secretary-General (n 34 above).

38 Sometimes a very treaty provision elucidates its meaning, eg Treaty of friendship and cooperation between Spain and Russian Federation, Madrid, 12.4.1994, art. IX: 'The Kingdom of Spain and the Russian Federation shall accord special attention to the strengthening of cooperation with respect to the functioning of democratic institutions and the rule of law. Such cooperation shall cover, inter alia, the following areas: Constitutional, legislative and regulatory standards; The monitoring of constitutionality and legality; Human rights and the rights of citizens; Political and electoral systems'.

39 Art 14 ICCPR.

40 'Report of the Secretary-General on Strengthening and Coordinating United Nations Rule of Law Activities' (29.7.2013), A/68/213. 
of governmental actions in hierarchical domestic society to more substantial law-obedience in a community of equal sovereigns; this feature is clearly visible in a particular international element inserted, aimed at implementation of the UN Charter's obligations.

\section{Rule of law in Africa}

This omnipresent chorus of incantations regarding the rule of law raises an untimely question as to its alleged customary normative character. It was invoked as such, for example, by an applicant before the African Court who claimed that the initiation in Tanzania of a constitutional amendment to settle a legal dispute, which was pending a judicial decision, amounted to a violation of the principle of the rule of law in force as a customary international law. The African Court decisively denied and explained that 'the rule of law is an all-compassing principle under which human rights fall and so cannot be treated as abstract or wholesale.. ${ }^{41}$ This brief statement aptly reflects the elusive nature of the rule of law taken as such (even putting aside the question of whether the term 'principle' which suggests the normative potential thereof - was applied appropriately) but, at the same time, implicite assumes its axiomatic dimension in legal discourse on good governance within domestic legal systems. Furthermore, if the latter were true it would be senseless to dwell upon regional or cultural particularities in perceiving the rule of law, since the fundamental nature of the idea would effectively prevent such relativism. As a matter of fact, denunciation of the most fundamental tenet of the idea (that is to say: ruling by law) would amount to an unprecedented retrogression destroying all patterns of social symbiosis as we have known it from time immemorial. Nevertheless, with its assembly-toy character and the variety of 'bricks' available and ready to be arranged in various ways, it cannot be excluded (at least in theory) that a kind of regionalisation in this respect is possible, allowing certain elements to be picked and accentuated while others are marginalized.

Apart from an isolated attempt by the African Court to characterize (in a sort of negative way) the nature of the domestic rule of law, this label

41 Tanganyika Law Society, The Legal and Human Rights Centre \& Reverend Christopher Mtikila v The United Republic of Tanzania African Court (14.6.2013) para 121. 
is not infrequently mentioned in decisions of the African Commission. They reveal no clear traces of distortion from the abovementioned doctrinal presentation, thus resonating some formal and substantial elements alike. In particular, the rule of law brand was used by the African Commission to epitomise the fundamental feature of good governance: ruling by law ${ }^{42}$ qualified, when necessary, with formal legality requirements (non-retroactivity $^{43}$ or independence of the judiciary ${ }^{44}$ ). The substantive elements were present as well in pronouncements concerning the legal protection of individual rights. ${ }^{45}$ Similarly, the East African Court of Justice (EAC Court) found that an intervention by the armed security agents of Uganda to prevent the execution of a lawful court order had violated the principle of the rule of law. A binding court decision constitutes the cornerstone of the independence of the judiciary and, conversely, constitutes one of the principles of the observation of the rule of law. ${ }^{46}$

It must not be overlooked, however, that African particularities and reflection thereon evidently underpinned a discourse regarding the shaping of the legal framework of the local human rights system. Its keystone document: the African Charter on Human and Peoples' Rights (African Charter ${ }^{47}$ was drafted to reflect African legal philosophy and respond to African needs. ${ }^{48}$ Hence the treaty itself reveals striking variations when compared to the other relevant international instruments. Its Preamble referrals to the 'aspirations of African people' and undertakings to 'eliminate

42 Antonie Bissangou v Congo (2006) AHRLR 80 (ACHPR 2006) para 77; Article $19 v$ Eritrea (2007) AHRLR 73 (ACHPR 2007) para 108; Zimbabwe Lawyers for Human Rights \& Associated Newspapers of Zimbabwe v Zimbabwe (2009) AHRLR 235 (ACHPR 2009) para 176.

43 Media Rights Agenda, Constitutional Rights Project, Media Rights Agenda and Constitutional Rights Project v Nigeria (2000) AHRLR 200 (ACHPR 1998) para 81.

44 Zimbabwe Lawyers for Human Rights and Institute for Human Rights and Development in Africa (on behalf of Andrew Barclay Meldrum) v Zimbabwe (2009) AHRLR 268 (ACHRP 2009) para 118; Communication 323/06, Egyptian Initiative for Personal Rights \& INTERIGHTS v Egypt, para 223 (http://caselaw.ihrda.org/doc/323.06/view/).

45 Constitutional Rights Project v Nigeria (2000) AHRLR 191 (ACHPR 1998) para 58; Zimbabwe Human Rights NGO Forum v Zimbabwe (2006) AHRLR 128 (ACHPR 2006) para 203; Communication 313/05, Kenneth Good v. Republic of Botswana, Twenty Eight Annual Activity Report, paras 193-194.

46 Katabazi \& Others $v$ Secretary-General of the East African Community \& Another (Katabazi Case), EAC Court (1.11.2007) (2007) AHRL 119, para 54.

${ }^{47}$ Banjul, 27.6.1981.

48 Introductory Note, 'International Legal Materials' 1982, vol. 21, p. 58. 
colonialism (...), apartheid, Zionism', it incorporates individual duties towards 'family, society and the State', merging civil and political rights with economic, social and cultural ones and introduces clawback clauses which entitle a state to restrict the granted rights to the extent permitted by domestic law - all of these factors make the African Charter stand apart. ${ }^{49}$ However a temptation to find its own, African path in developing theoretical foundations of the domestic rule of law was strongly deterred as early as during the peak of the decolonization process. At this time, the continent's 240,000,000 people were able to seek the assistance of fewer than 2,000 lawyers and only seven recognized law schools existed ${ }^{50}$ and upon independence all former colonies decided to adopt the legal systems of their metropoles. ${ }^{51}$ Rejection of traditional, pre-colonial legal patterns of administration of justice and governance ${ }^{52}$ - determined by prevailing social experience in made in Europe standards and amplified by spearheading elites formatted at French or British universities - effectively prevented any form of an ideological melting-pot to distil the rule of law à l'Africaine. The African conference on the rule of law, sponsored by the International Commission of Jurists, was held in Lagos in 1961, hosting nearly 200 judges, practicing lawyers and teachers of law from 23 African states. The Conference issued a final resolution, 'The Law of Lagos', accompanied by conclusions prepared by three committees. The 'Law of Lagos' recognized the rule of law without any parochial bias, as a dynamic concept which should be employed to safeguard and advance the will of the people, political rights of the individual and to establish social, economic, educational and cultural conditions under which the individual may achieve dignity. Committee II in its conclusion on human rights and aspects of criminal and administrative law explicitly described the rule of law as of universal

49 R. Gittleman, The African Charter on Human and Peoples' Rights: A Legal Analysis, 'Virginia Journal of International Law' 1982, vol. 22, p. 667 et seq.; R.M. D'Sa, Human and Peoples' Rights: Distinctive Features of the African Charter, 'Journal of African Law' 1985, vol. 29, p. 72 et seq.

50 C.S. Rhyne, Law in Africa: A Report on the Lagos Conference, 'American Bar Association Journal' 1961, vol. 47, p. 685.

51 S.F. Joireman, Inherited legal systems and effective rule of law: Africa and the colonial legacy, 'The Journal of Modern African Studies' 2001, vol. 39, p. 576.

52 This repudiation was not complete however, see eg (on South African practice) P.K. Rakate The status of traditional courts under the final constitution, 'The Comparative and International Law Journal of Southern Africa' 1997, vol. 30, pp. 175-189. 
validity and application ${ }^{53}$ thus adhering to the intellectual foundations of the idea that had been previously recognized by sovereign states outside Africa. In fact, it is deeply moving to study Rhyne's coeval report on the Conference, which mirrors the enthusiasm and zeal of its participants in shaping a new reality. And there is something poignant to read on $^{54}$ :

Prime Minister Balewa of Nigeria (...), a man of great charm (...) (whose) address on the rule of law was most inspiring. Anyone who (heard) him (would) immediately conclude that Africa's largest republic has chosen a wise leader whose presence and voice on the world scene should become increasingly significant. When he said 'there is no need to destroy individual human rights to secure public security', he obviously was expressing a deeply felt conviction.

Balewa was killed during the first Nigerian army coup in 1966 and his fate symbolizes a hiatus between the laudable declarations of the individuals gathered in Lagos and the bitterly disappointing every-day practice after 1961 . This practice is roughly described by the Worldwide Governance Indicators (WGI), one of a few rule of law measures, ${ }^{55}$ a project headed by Kaufmann, Kraay and Mastruzzi (affiliated with the World Bank Institute or the Development Research Group of the World Bank) that covers more than 200 states and territories and presents selected composite indicators of a broad dimension of governance. The rule of law indicator capture 'perceptions of the extent to which agents have confidence in and abide by the rules of society, and in particular the quality of contract enforcement, property rights, the police, and the courts, as well as the likelihood of crime and violence ${ }^{56}$ and reveals significant deficiencies in Africa. The map of WGI for 2012 classifies states and territories into six percentile ranges with no African states in the two top and only four African states (Botswana, Ghana, Namibia and RSA) reaching the third highest range (along with, for example, India and Brazil). ${ }^{57}$

53 The Lagos Law and conclusions in: M.C. Bassiouni, Z. Motala (eds) 'The Protection of Human Rights in African Criminal Proceedings' Dordrecht 1995, p. 438 et seq.

54 Rhyne (note 50 above), p. 686.

55 S.E. Skaaning Measuring the Rule of Law, 'Political Research Quarterly' 2010, vol. 63, p. 449 et seq.

56 D. Kaufmann et al (note 19 above), p. 4.

57 http://info.worldbank.org/governance/wgi/index.aspx\#reports (accessed 30.11.2013). 
However, putting bitter practice aside, it is striking that the (domestic) rule of law - as a package for good governance, universally accepted but susceptible to different arrangements - became strongly anchored in principal, regional international agreements ${ }^{58}$ and non-binding documents ${ }^{59}$ which reveal no traces of local particularities or attempts to create a kind of exotic and rough version of the rule of law for juntas or totalitarian

58 The Constitutive Act of the African Union (AU), Lome, 11.7.2000: Art 4(m) mentions 'respect for democratic principles, human rights, the rule of law and good governance' among principles of AU. Protocol to the Treaty Establishing the African Community Relating to the Pan-African Parliament, Sirte, 2.3.2001: Art 11(1) empowers the Parliament to examine, discuss or express its opinion on any matter pertaining to respect of human rights, the consolidation of democratic institutions and the culture of democracy, as well as the promotion of good governance and the rule of law. Protocol Relating to the Establishment of the Peace and Security Council of AU, Durban, 10.7.2002 uses 'the rule of law' to shape legal coordinates as to: objectives of the Council in Art 3(f), principles the Council to be guided by in Art 4(c), criteria with regard to each prospective Member of the Council in Art 5(2)(g), powers of the Council in Art 7(1)(m) and its particular peace-building competence in Art 14(1). African Youth Charter, Banjul, 2.7.2006, in Art 26(j) calls the Youth to 'defend democracy, the rule of law and all human rights and fundamental freedoms'. African Charter on Democracy, Elections and Governance, Addis Ababa, 30.1.2007, was agreed to 'promote and enhance adherence to the principle of the rule of law premised upon the respect for, and the supremacy of, the Constitution and constitutional order in the political arrangements of the State Parties, as provided in Art 2(2) and Art 4(1). Outside AU system, Treaty for the Establishment of the East African Community, Arusha, 30.11.1999, in Art 3(3)(b) sets 'adherence to universally acceptable principles of good governance, democracy, the rule of law, observance of human rights and social justice' as a condition of membership. The SADCT (note 3 above) in Art 4(c) again places 'human rights, democracy and the rule of law' as organizational principles. A special attention should be paid to the Protocol on Democracy and Good Governance Supplementary to the Protocol relating to the Mechanism for Conflict Prevention, Management, Resolution, Peacekeeping and Security, Economic Community of West African States, A/SP1/12/01, Dakar, December 2001. The document contain relatively detailed reference to fundamental qualities of the rule of law. In particular Art 33 provides that 'the rule of law involves not only the promulgation of good laws that are in conformity with the provisions on human rights, but also a good judicial system, a good system of administration, and good management of the state apparatus'.

59 E.g. The First OAU Ministerial Conference on Human Rights, Grand Bay (Mauritius) Declaration and Plan of Action, April 1999, affirming 'the interdependence of the principles of good governance, the Rule of Law, democracy and development' and recognizing 'that the development of the rule of law, democracy and Human Rights calls for an independent, open, accessible and impartial judiciary, which can deliver justice promptly and at an affordable cost. To this end, such a system requires a body of professional and competent judges enjoying conducive conditions'. 
regimes. On the contrary, these instruments apparently clearly adhere to the classical tenets of the idea. A treaty-based implantation of a phrase 'the rule of law' into legal and political interstate discourse certainly cannot uproot domestic practices which are incompatible therewith, just as the famous Article 2(4) of the UN Charter could hardly eliminate the use of force in international relations. However, providing a separate factor of the rule of law, even if it is one to be used solely for opportunistic reasons and to achieve a short-term political gain, leads international relations to become inundated with rule of law rhetoric. This, in turn, may generate an impetus to strengthen the fragile idea and sublimate mechanism to advance particular elements of the concept or any added value inherent to it (if any). The vast array of possible measures includes, for example, conferences promoting good governance ${ }^{60}$ capacity-building programs, ${ }^{61}$ non-binding resolutions, ${ }^{62}$ treaties, ${ }^{63}$ and instruments of judicial protection (to be discussed later).

In fact there may be, from case to case, an evident iunctim between ignoring the rule of law within the domestic sphere and doing the same on the international level, since adherence to the rule of law practically demonstrates a state's attitude towards any legal framework arranging communal life: whether domestic or international. Zimbabwe is presumably an illustrative example in this respect. But this relation cannot be described as omnipresent and the fate of the SADC Tribunal alone does not represent a sufficient basis to project the abovementioned conclusion regarding the domestic rule of law onto international relations between African states. In particular, there are no ritual academic lamentations regarding an endemic disregard for the rule of law in the United States following its non-appearance at the merits phase and its subsequent defiance of the International Court of Justice (ICJ) judgment in the Nicaragua v. US

60 E.g. 4th East African Community Annual Conference on Good Governance, Kigali, 8.7.2013.

61 E.g. Common Market for Eastern and Southern Africa support for electoral process in Sudan, see http://www.comesa.int/index.php?option=com_content\&view=article\&id=887: comesa-to-participate-in-sudan-electoral-process\&catid=5:latest-news\&Itemid=41 (accessed 30.11.2013).

62 African Commission, Resolution nr 235 of 23.4.2013 on Transitional Justice in Africa, http://www.achpr.org/sessions/53rd/resolutions/235/ (accessed 30.11.2013).

63 E.g. Protocol on Democracy and Good Governance, Dakar, 21.12.2001, http:// www.comm.ecowas.int/sec/en/protocoles/Protocol\%20on\%20good-governance-and-democracy-rev-5EN.pdf (accessed 30.11.2013). 
$\operatorname{Case}^{64}$ or its failure to enforce the provisional measures handed down by the ICJ in the La Grand Case. ${ }^{65}$

Consequently the suspension of the SADC Tribunal could be approached as part of a scientific discussion on the rule of law in Africa primarily in the context of the international dimension of the rule of law, embodying at least predictability and the legitimacy of state actions, as well as full implementation of the obligations laid down in international instruments. This issue cannot be tackled without an analysis of a particular problem that underpinned the SADC Tribunal's destiny.

\section{African regional courts - raids on the unspeakable}

\subsection{A general overview}

The SADC was established in 1992 to replace the Southern African Development Coordination Conference, which had been formed twelve years before as an informal platform of cooperation in economic and political matters between a group of Southern African states. The absence of a precise legal framework for collaboration, in conjunction with certain political and economic factors (such as the democratic transformation which occurred in the RSA and the emergence of trading arrangements in other parts of the world), induced the transformation of the Conference into the present day SADC. ${ }^{66}$ The event harmonized with a broader process of developing sub-regional integration instruments leading to the creation of regional economic communities (RECs). AU has recognized eight of them as officially representative regional associations of African states. ${ }^{67}$ While

64 Military and Paramilitary Activities in and Against Nicaragua Case ICJ (26.11.1984, Jurisdiction and Admissibility) (1984) ICJ Reports 392; (27.6.1986, Merits) (1986) ICJ Reports 14.

${ }^{65}$ FRG v US, 526 US 111 (1999).

66 C. Ng'ong'ola, Regional integration and trade liberalization in the Southern African development community, 'Journal of International Economic Law' 2000, vol. 3, p. 485-506.

67 The Community of Sahel-Saharan States (CEN-SAD), The Common Market for Eastern and Southern Africa (COMESA), The East African Community (EAC), Economic Community of Central African States (ECCAS), Economic Community of West African States (ECOWAS), Intergovernmental Authority for Development (IGAD), SADC and Union du Maghreb Arabe (UMA). 
the original purpose of sub-regional cooperation in Africa and elsewhere was to strengthen economic relations and to create a platform for advancing local interests in international relations, ${ }^{68}$ intersections between economic integration and human rights are not uncommon in relevant treaties. In fact, the protection of human rights became a standard element of communities' principles phraseology. ${ }^{69}$ In this way SADCT proclaimed in article 4(c) that 'SADC and its Member States shall act in accordance with the principle of human rights, democracy and the rule of law. Article 6(1) confirms that:

Member States undertake to adopt adequate measures to promote the achievement of the objectives of SADC, and shall refrain from taking any measure likely to jeopardize the sustenance of its principles, the achievement of its objectives and the implementation of the provisions of this Treaty.

The inclusion of general human rights clauses in international treaties constitutive for RECs was accompanied by the establishment of international tribunals as judicial organs in six of the eight RECs (two exceptions are CEN-SAD and IGAD), albeit that two of the RECs retain their courts as non-operational (ECCAS, and UMA). This, in turn, has fuelled discussion regarding the role of these international courts in protecting human rights and, in particular, on their competence to deal with individual applications for relief from human rights violations. The clue is a frequent indeterminacy which is found in the RECs courts' mandates. While, as a rule, individual

68 K.O. Kufuor, The African Human Rights System. Origin and Evolution, New York 2010, p. 99 et seq.

${ }^{69}$ The Revised Treaty of ECOWAS, Cotonou, 24.7.1993, declares in Art 4(g) that the high contracting parties adheres to the principle on 'recognition promotion and protection of human and peoples' rights in accordance with the provisions of African Charter. The Treaty Establishing COMESA (COMESA Treaty), Kampala, 5.11.1993, stipulates in Art 6(e) recognition, promotion and protection of human and peoples' rights in accordance with the provisions of ACHR as one of fundamental principles of COMESA. The Amended Treaty for the Establishment of EAC (EACT), Arusha, 30.11.1999, provides in Art 6(d) that 'The fundamental principles that shall govern the achievement of the objectives of the Community by the Partner States shall include: good governance including adherence to the principles of democracy, the rule of law, accountability, transparency, social justice, equal opportunities, gender equality, as well as the recognition, promotion and protection of human and peoples rights in accordance with the provisions of the African Charter on Human and Peoples' Rights'. 
access to sub-regional courts is provided for in the various COMESA, ${ }^{70}$ EAC, ${ }^{71}$ ECOWAS and SADC ${ }^{72}$ treaties, only the ECOWAS Court was explicitly granted competence to adjudicate upon human rights issues. ${ }^{73}$ As a result, it soon became the most resilient African regional forum in the field of human rights. As of December 2009, over $85 \%$ of cases concluded by the ECOWAS Court concerned alleged human rights violations within ECOWAS member states, and nothing has suggested that this trend will abate. ${ }^{74}$ However, three other judicial institutions were significantly less privileged. With a generous dose of legal uncertainty driven by silence in the COMESA and SADC treaties (or just an alleged restraint expressed

70 COMESA Treaty, Art 26: 'Any person who is resident in a Member State may refer for determination by the Court the legality of any act, regulation, directive, or decision of the Council or of a Member State on the grounds that such act, directive, decision or regulation is unlawful or an infringement of the provisions of this Treaty: Provided that where the matter for determination relates to any act, regulation, directive or decision by a Member State, such person shall not refer the matter for determination under this Article unless he has first exhausted local remedies in the national courts or tribunals of the Member State'.

71 EACT, Art 30 (1): 'Subject to the provisions of Article 27 of this Treaty, any person who is resident in a Partner State may refer for determination by the Court, the legality of any Act, regulation, directive, decision or action of a Partner State or an institution of the Community on the grounds that such Act, regulation, directive, decision or action is unlawful or is an infringement of the provisions of this Treaty'. Jurisdiction to deal with human rights cases was apparently barred by Art 27(2): 'The Court shall have such other original, appellate, human rights and other jurisdiction as will be determined by the Council at a suitable subsequent date. To this end, the Partner States shall conclude a protocol to operationalise the extended jurisdiction', as an adequate protocol has not been concluded so far.

72 Protocol on Tribunal in the Southern African Development Community (Protocol), Windhoek, 7.8.2000, Art 15(1): 'The Tribunal shall have jurisdiction over disputes between States, and between natural or legal persons and States'.

${ }^{73}$ Originally individuals lacked access to the ECOWAS Court under ECOWAS treaties, see: Afolabi Oladjide v Nigeria [2004] ECOWAS Court ECW/CCJ/JUD/01/04 (27.4.2004). It was only Supplementary Protocol A/SP.1/01/05 Amending the Protocol Relating to the Community Court of Justice, Accra, 19.1.2005, that equipped the Court with human rights jurisdiction. Pursuant to Art 9(3) of the amended Protocol: 'The Court has jurisdiction to determine case of violation of human rights that occur in any Member State'. Art 10(d) thereof provides that: 'Access to the Court is open to (...) Individuals on application for relief for violation of their human rights (...)'.

74 S. Ebobrah, A. Tanoh (eds), Compendium of African Sub-Regional Human Rights Documents, Pretoria 2010, p. 261. 
in $\mathrm{EACT}^{75}$ ) regarding their courts' jurisdiction in human rights cases, the relevant courts had to refer, if necessitated by individual petitions, to their competence de la competence to define more precisely the parameters of their authority. As a matter of fact, only the two latter organs faced this challenge, since the COMESA Court by focusing in its jurisprudence on complex procedural dilemmas did not appear to be the most amicable forum before which to resolve human rights issues and it has not received any human rights cases to date. ${ }^{76}$

\subsection{EAC Court}

Considering that the human rights jurisdiction of EAC Court was to remain indefinitely dormant, given the absence of any a triggering proto$\mathrm{col}^{77}$ its decision to assert its 'derivative human rights competence ${ }^{78}$ in the Katabazi Case was rather astonishing. ${ }^{79}$ The claimants maintained that the invasion of a domestic court's premises by the armed agents of a state party, combined with the subsequent re-arrest within those premises of persons who had been granted bail by that court, amounted to a violation of the principle of good governance. The respondents raised preliminary objection alleging that the EAC Court lacked the jurisdiction ratione materiae to deal with human rights petitions until such jurisdiction would be granted under article 27(2) EACT. The EAC Court tackled the problem with an unparalleled, concise bluntness: ${ }^{80}$

Does this Court have jurisdiction to deal with human rights issues? The quick answer is no it does not. Jurisdiction of this Court is provided by article 27 (...). It very clear that jurisdiction with respect to human rights requires a determination of the Council and a conclusion of a Protocol to that effect. Both of those steps have not been taken. It follows, therefore, that this Court may not adjudicate on disputes concerning violation of human rights per se.

$75 \quad$ EACT (note 69 above) Art. 27.

76 See F. Viljoen, International Human Rights Law in Africa, Oxford 2012, p. 494.

77 EACT (note 69 above) Art 27 (2).

78 The term used by ST Ebobrah, Litigating Human Rights Before Sub-Regional Courts in Africa: Prospects and Challenges, 'The African Journal of International and Comparative Law' 2009, vol. 17, p. 82.

79 Note 46 above.

80 Paras 33-34. 
But instead of dismissing the claimant's reference, the EAC Court went on to consider the issue with a meaningful passage: 'However, let us reflect a little bit'. In fact it took no more than a half of a standard page (five short paragraphs, four of which solely citing Articles 5-8 of EACT) to conclude with a sentence-long substantial distinction: ${ }^{81}$

While the Court will not assume jurisdiction to adjudicate on human rights disputes, it will not abdicate from exercising its jurisdiction of interpretation under article 27(1) merely because the reference includes allegation of human rights violation.

With the doors wide open then to decide upon the merits of the reference, the EAC Court held that the intervention by the armed security agents of Uganda to prevent the execution of a lawful court order had violated the rule of law principle and consequently infringed article 7(2) EACT, which provides that the partner states undertake to abide by the principles of good governance, including adherence to the principles of democracy, the rule of law, social justice and the maintenance of universally accepted standards of human rights. ${ }^{82}$ With no attempt whatsoever to explain the nebulous difference between its impermissible 'adjudication on human rights disputes' and its permissible 'jurisdiction to interpret the EACT with a human rights component' in cases referred by individuals, the EAC Court was exposed to allegations of excessive judicial activism that might have been perceived as a judicial re-writing of the EACT. Or - to put it less euphemistically - as a violation of the convention.

To avert an odd impression of an ancient tragedy in the courtroom with the EAC Court cast in the role of Prometheus and secretly, under the disguise of perfect legalism, sacrificing the international rule of law only to spare the domestic rule of law - the EAC Court the was required to present much more persuasive reasoning to justify the stance it adopted in the Katabazi Case. The traces of such a defence were clearly visible in an appellate decision on the IMLU Case $^{83}$ but were only fully developed later, in

$81 \quad$ Para 39.

82 Para 54.

83 Attorney General of Kenya v Independent Medical Legal Unit EAC Court (15.3.2012): 'The significance and genius of the Katabazi case is not so much in the Court's famous refusal 'not to abdicate' its jurisdiction. Rather, it was the Court's ability to find and supply, through interpretation of the Treaty, the source and basis for the Court s jurisdiction in the circumstances of the case then before the Court. To this end, the Court in the Katabazi case proceeded to probe, to examine and to asses at great length and 
the Samuel Mukira Mohochi Case. ${ }^{84}$ The applicant travelled to Uganda from Kenya as part of a delegation of the International Commission of Jurists. On arrival at Entebbe International Airport he was not allowed beyond the immigration checkpoint and was subsequently put on a Nairobi-bound flight and returned to Kenya. The immigration authorities did not inform him why he had been denied entry or why he had been declared a prohibited immigrant. The applicant contended inter alia that these actions had violated his fundamental rights and freedoms: against discrimination, from arbitrary arrest and detention, to a fair and just administrative action, to information and of assembly, association and movement - as guaranteed by articles 2,6,7,9,10,11 and 12 of the African Charter. The respondent's rebuttal claimed that the EAC Court had no jurisdiction to enforce these provisions. The EAC Court dealt with these contentions by offering a sound pronouncement regarding the nature of the EACT: it is not a human rights convention but an instrument for deepening the political, economic, social, cultural, research, technology, defence, security, legal and judicial cooperation between partner states. In particular no part of the EACT, its protocols or annexes designates any provisions therein as being 'human rights provision'. The EAC Court noted that the applicant had invoked the relevant stipulations of the African Charter as recognised by articles 6(d) and 7(2) EACT. Consequently, the EAC Court understood that the cause of action in the case concerned the alleged infringement of a partner state's treaty obligations, which constituted a matter falling outside the province of human rights. In other words, for the EAC Court it was not the violation of human rights under the laws of Uganda or international law outside the EACT which constituted the cause of action, but rather a specific allegation of infringements of EACT provisions by the Ugandan government. ${ }^{85}$ Moreover, the EAC Court had no doubt that article 27(2) clause forms nothing more than a prefiguration to extend its jurisdiction in the future and in particular not as a bar or derogation for pre-existing jurisdiction to interpret the provisions of the EAC. ${ }^{86}$ Accordingly, although the EAC Court

in great depth the source that allowed the Court to claim and exercise jurisdiction in the matter. They found and supplied the cause of action flowing from the Treaty (that was different and distinct from violation of the human rights) on which to peg the Court's jurisdiction [my emphasis]'.

84 Samuel Mukira Mohochi $v$ The Attorney General of the Republic of Uganda The EAC Court (17.5.2013).

${ }_{85}$ Paras 28-32.

86 See also Plaxeda Rugumba v The Attorney General of Rwanda EAC Court (1.12.2011). 
accepted referrals to the African Charter in order to decode the precise parameters of the regional standard of protection against alleged human rights violations, the findings on violations did not go beyond invocations of provisions contained in the EACT or protocols thereto.

The EAC Court carved the limits of its present-day competence by trying to bring together an existing jurisdiction to interpret the human rights principle embodied in the EACT and the awkward wording of article 27 regarding the other still unspecified original, appellate and human rights jurisdiction which remains to come. Its bravery in this respect was alleged to have amounted to judicial activism and ultra vires conduct but, on the other hand, the case-law demonstrated the ability of the EAC Court's judges to aptly avoid obvious violations of international legal norms governing treaty interpretation. Ambiguities are inherently embodied in legal texts of any kind and generate ongoing disputes on their application. And that is why lawyers will always be as snug as bugs in a rug. Article 31(1) of the Vienna Convention on the Law of Treaties (VCLT) requires that a treaty be interpreted 'in good faith in accordance with the ordinary meaning to be given to the terms of the treaty in their context and in the light of its object and purpose.' It seems therefore that when two or more acceptable readings of a given provision exist, the one should be preferred that more accurately comply with the treaty's object and purpose. But the directive given by article 31(1) VCLT does not always help to discover the objective and universally accepted truth as to the meaning of interpreted norm. And this is when a conflict between both (or more) different ways of a legal texts' reading cannot be solved in an absolutely convincing manner. In the present case, the EAC Court preferred an interpretation that values human rights protection within a community legal system.

In particular, when an implicite confirmation of the EAC Court's legitimism in this respect is sought, one should not omit the meaningful silence of other EAC organs or partner states confronted with the EAC Court's relevant decisions. Even the Tanzanian President, who rarely beat about the bush while criticizing the SADC's Tribunal stance towards its jurisdiction, displayed significant restraint and refrained from censuring the EAC Court. In fact, the EAC Court itself has started to exert strong judicial pressure over the EAC Council to double its efforts and fill the gap in the EAC Court's jurisdiction in accordance with article 27(2) EACT. In 2011, the EAC Court decided that quick action should be taken by the organization to 
operationalise such extended jurisdiction. ${ }^{87}$ Accordingly, a process leading to the extension of jurisdiction was ultimately initiated, although it has not been implemented in an efficient way and aimed somewhat odd objectives. On 26.4.2012, the East African Legislative Assembly adopted a resolution demanding that the EAC Council implore the International Criminal Court to transfer the case of the accused four Kenyans facing trial in respect of the aftermath the 2007 Kenya general elections to the EAC Court. The last operative part of this resolution was intended as a driving factor to the 10th Extra-Ordinary Summit of EAC Heads of State (EAC Summit) to amend article 27 EACT and provide the EAC Court with such 'other' jurisdiction as is necessary to cover crimes against humanity with retroactive effect. ${ }^{88}$ The EAC Summit welcomed the resolution and directed the EAC Council to consider this issue. ${ }^{89}$ In November 2013, the EAC Council still remained seized of the matter ${ }^{90}$ as did the EAC Court which, in June 2012, commenced hearing a case initiated by Sitenda Sebalu (an Ugandan member of parliament) against the Secretary General of the EAC for alleged failure to implement the judgment of 30.6.2011 (Reference 8 of 2012).

The story of the EAC Court and its efforts to clarify the scope of its competence mirrors, to some extent, a similar approach of the Court of Justice of the European Union (CJEU), which famously declared that a doctrine of fundamental human rights was enshrined as a general principle of community law and was protected by the CJEU, ${ }^{91}$ thereby subordinating national interests to community principles. ${ }^{92}$ Both processes prima facie shared a common feature: member states confronted with a progressive judicial interpretation of the constitutive treaties regarding their courts' jurisdiction, complied with the court's judgment and displayed a distinctive

87 Sitenda Sebalu v The Secretary General of the EAC \& Others EAC Court (30.6.2011).

$88 \mathrm{http} / / /$ www.eala.org/component/docman/cat_view/45-key-documents/46-resolutions.html (accessed 30.11.2013).

89 'Communiqué of the 10th Extraordinary Summit of EAC Heads of State' (28.4.2012).

90 http://allafrica.com/stories/201311180300.html (accessed 30.11.2013).

91 Stauder v City of Ulm, Sozialamt, Case 29-69, judgement of 12.11.1969, ECLI:EU:C:1969:57. See also: Internationale Handelsgesellschaft v EVGF, Case 11-70, judgement of 17.12.1970, ECLI:EU:C:1970:114; Nold, Kohlen und Baustoffgroßhandlung $v$ Commission of the European Communities, Case 4-73, judgement of 14.5.1974, ECLI:EU:C:1974:51.

92 E.g. Rewe-Zentral AG v Bundesmonopolverwaltung für Branntwein, Case 120/78, judgement of 20.2.1979, ECLI:EU:C:1979:42. 
submissiveness. ${ }^{93}$ Such compliance seems natural, mandatory in fact, as states' compliance with judicial pronouncement is central to the very idea of legality. Obedience vis-à-vis the law always forms an intrinsic element of the rule of $l a w^{94}$ and, as such, forms a welcomed feature from the standpoint of international law and international relations. Although an archetypical concept of the rule of law should always set basic parameters for resolving possible conflicts between political and judicial organs of international organizations facing disputes over their respective powers, the devil is in the politics. The fate of the SADC Tribunal forms an illustrative example.

\subsection{SADC Tribunal}

The establishment of the SADC Tribunal, one of the eight treaty-based SADC institutions, was envisaged by article 9(1)(g) SADCT. Under article 16, it was generously vested with contentious, appellate and advisory jurisdiction to ensure adherence to, and the proper interpretation of, the provisions of the SADCT and subsidiary instruments. While such concise stipulations of the SADCT required due supplementation in order to enable the creation and operation of the judicial body, they were followed nearly a decade later by a Protocol. ${ }^{95}$ Under Article 14 of the Protocol, the ratione materiae jurisdiction of the SADC Tribunal was crafted to make it the guardian of the SADC's legal framework and comprised inter alia the interpretation and application of the SADCT and its protocols. A fairly wide personal jurisdiction enabled the SADC Tribunal to rule on disputes between natural and legal persons and member states or the SADC (articles 15(1) and 18(1) Protocol). But an inconspicuous phrase contained in article 4(c) SADCT provided that 'the SADC and its Member States shall act in accordance with the principle of human rights, democracy and the rule of law', and a brief note in the preamble regarding human rights and the rule of law, combined with the absence of any direct references to the African Charter,

93 In fact one cannot exclude a possibility of political pressure exerted upon CJEU and influencing its decision-making process, see C.J. Carubba et al., Judicial Behavior under Political Constraints: Evidence from the European Court of Justice, 'American Political Science Review' 2008, vol. 102, pp. 447-449.

94 A.V. Huneeus Compliance with International Court Judgments and Decisions, 'University of Wisconsin Law School Legal Studies Research Paper' 2013, series 4, no 1219.

95 Note 72 above. 
confirmed that the SADC Tribunal was not intended to be established as a human rights court dedicated to control compliance with relevant human rights conventions.

Delivering its judgment in the Campbell Case, ${ }^{96}$ the SADC Tribunal focused on four main issues. While three of them were directly related with the core of the individuals' claims and referred to alleged violations of human rights by Zimbabwe (in particular: access to justice, prohibition of racial discrimination, just compensation in respect of expropriated property), the fourth - the preliminary issue - was based on the respondent's submission that the SADC Tribunal lacked the jurisdiction to entertain the application under the SADCT. In particular, the respondent focused on ratione materiae jurisdiction and maintained that neither the SADCT nor its protocols constitute typical human rights treaties and, whilst they may set out the principles and objectives of the SADC, they do not establish any legal standards against which the actions of member states can be assessed. To borrow such standards from other treaties would amount to unacceptable legislating on behalf of the SADC member states.

It seems evident that the SADC Tribunal, faced with the preliminary objection to its jurisdiction, found itself at a crossroads. To decide which way to follow was to determine its place within the SADC's structure. Ostensibly this did not constitute a to-be-or-not-to-be kind of question but inevitably it required that the Tribunal define the scope of its subject-matter jurisdiction and, as a result, the character of the judicial organ itself. Had the SADC Tribunal ruled in line with the respondent's contention (a pragmatic solution 'to please the lions', not necessarily requiring any obvious distortion of the SADCT and raising no serious danger apart from the occasional angry growls of certain academics), it would have probably positioned this judicial organ as a flourishing administrative court of the community - one which dealt mainly with employment and infrequent interstate or member state versus organization disputes, but certainly not a human rights court setting-out legal standards by which member states' conduct will be assessed. The SADC Tribunal chose otherwise, passing the Rubicon in a mere few phrases:

In deciding this issue, the Tribunal first referred to Article 21(b) (of the Protocol) which, in addition to enjoining the Tribunal to develop its own jurisprudence, also instructs the Tribunal to do so having 
regard to applicable treaties, general principles and rules of public international law which are sources of law for the Tribunal. That settles the question whether the Tribunal can look elsewhere to find answers where it appears that the Treaty is silent. In any event, we do not consider that there should first be a Protocol on human rights in order to give effect to the principles set out in the Treaty, in the light of the express provision of Article 4(c) of the Treaty which states as follows: 'SADC and Member States are required to act in accordance with the following principles - (...)(c) human rights, democracy and the rule of law'. It is clear to us that the Tribunal has jurisdiction in respect of any dispute concerning human rights, democracy and the rule of law, which are the very issues raised in the present application.

Having settled the preliminary problem, the SADC Tribunal went on to tackle the merits and held that Zimbabwe was in breach of its obligations under Article 4(c) and 6(2) SADCT (prohibition of discrimination). The respondent was also ordered to take all necessary measures to protect the possession, occupation and ownership of the lands of the applicants and to pay fair compensation to applicants that had already had been evicted from their lands. Faced with the clearly malevolent attitude of the Zimbabwean government, the SADC Tribunal ruled twice on non-compliance and resolved to report its findings to the SADC Summit for appropriate action to be taken, pursuant to Articles 32(5) and 32(4) Protocol. ${ }^{97}$ The SADC Summit responded oddly, by imposing a moratorium on the SADC Tribunal's ability to hear cases, failing to reappoint its members and commencing a review of the Protocol itself. ${ }^{98}$

Trying to identify the factors that could determine the different scores of the EAC Court and the SADC Tribunal on the wheel of fortune in their pursuit to define the scope of their respective jurisdictions, one could refer to at least four such factors, having diverse relevance. Two of such factors, one procedural and one substantive, seem to be substantially insignificant: although the EAC Court acts without a protocol as the judicial organ of the Community (unlike the SADC Tribunal), nevertheless Articles 23-47 of EACT provides a basis for the EAC Court's administrative and judicial activities and these provisions contain the same apparent lacuna regarding human rights competence. Similarly, there is no reason to argue

97 William Michael Campbell \& Richard Thomas Etheredge $v$ The Republic of Zimbabwe (2009) SADC 3 Tribunal (5.6.2009); Louis Karel Fick \& Others $v$ The Republic of Zimbabwe (2010) SADC Tribunal 8 (16.7.2010).

98 Note 5 above. 
that the SADCT's failure to refer to the African Charter (unlike the EACT) suffices to disqualify the SADC Tribunal's decision regarding its human rights jurisdiction. Although it was occasionally submitted that the mere human rights principles contained in the SADCT (not substantiated with African Charter stipulations) are of non-binding effect and intrinsically non-justiciable, ${ }^{99}$ the allegation seems untenable from the perspective of international practice. ${ }^{100}$ On the other hand, decisive elements were, quite foreseeably, not legal in nature but rather of a political character. Compliance with the SADC Tribunal's judgment in the Campbell Case would require the cessation of land reform in Zimbabwe, which had been underway since the transitional justice process and, at least declaratively, had strong moral support (the peasants needed the land, the war of liberation was fought for the land, and Zimbabweans were only taking back land that was originally stolen from them ${ }^{101}$ ). Against this background, the SADC Tribunal's decision in the Campbell Case constituted nothing less than a stirring-up of a hornets' nest located directly in front of the noses of Mugabe and the ZANU-PF. The EAC Court's rulings in the Katabazi or Samuel Mukira Mohochi Cases clearly lacked such profound and sensitive political implications and did not amounted to putting a gun to the partner states' heads.

To make a bad situation even worse: while the EACT does not provide a robust system of political control to ensure compliance with the EAC Court's rulings, ${ }^{102}$ within the SADC legal system such supervisory function is performed by the SADC Summit: any failure by a member state to comply with a decision of the SADC's Tribunal may be referred to it again by any party concerned. If the SADC Tribunal establishes the existence of such a failure, it shall report its finding to the SADC Summit in order that the latter may take appropriate action (Articles 32(5) and 32(4) of the Protocol). The mere existence of such an instrument positioned member

99 L. Bartels Review of the Role, Responsibilities and Terms of Reference of the SADC Tribunal. Final Report of 6 March 2011 (unpublished), p. 9-10.

100 Yassin Abdullah Kadi $v$ Council of the European Union and Commission of the European Communities; Al Barakaat International Foundation v. Council of the European Union and Commission of the European Communities, Joined cases C-402/05 P and C-415/05 P, judgement of 3.9.2008, ECLI:EU:C:2008:461.

101 For critical analysis see WH Shaw "They Stole Our Land": debating the expropriation of white farms in Zimbabwe, 'Journal of Modern African Studies' 2003, vol. 41, p. 75-89.

102 Article 38(3) EACT provides that 'A Partner State or the Council shall take, without delay, the measures required to implement a judgment of the Court'. 
states at a crossroads: to act in accordance with the international rule of law requirements and to comply with a judicial decision or to abandon it and invoke inter-state solidarity and SADC unity? ${ }^{103}$ The SADC's member states decided to act 'in such a high-handed and imperious manner, worthy of potentates or kings who can do no wrong and who are not accountable for their actions ${ }^{104}$ and to render an inconvenient judicial organ un-operational.

\section{Conclusion}

Judge Mzikamanda of Malawi alarmed and has said: ${ }^{105}$

The suspension of the SADC Tribunal, the judicial organ of the regional grouping, is quite telling. Among other things, it demonstrates how disregard for the rule of law at national level can manifest itself at the regional level through influential members of the regional grouping.

This is sad and possibly true, but haven't reports regarding 'the endemic disregard for the rule of law' in Africa been greatly exaggerated? In fact, to some extent they resemble an ominous pronouncement by the European Union's Justice Commissioner regarding a 'true rule of law crisis' within the Union, during a lament regarding the plight of Roma in France, the Hungarian right-wing stance and a Romanian political crisis. ${ }^{106}$ The later enunciation, while catchy and creating the image of a

103 President J Zuma made it clear stating that: '(The Tribunal) that got dismantled was because of the specific objection that one country made' see: http://www.news24. com/SouthAfrica/Politics/Zuma-suggests-alternative-SADC-tribunal-20131106 (accessed 30.11.2013).

104 'SADC Tribunal Dissolved by Unanimous Decision of SADC Leaders' transcript of a speech by AG Pillay, former President of SADC Tribunal (undated) 18, http://www. osisa.org/sites/default/files/article/files/Speech\%20by\%20former\%20President\%20 of\%20SADC\%20Tribunal.pdf (accessed 30.11.2013).

105 R.R. Mzikamanda 'Constitutionalism and the Judiciary: A Perspective from Southern Africa' (2011) paper delivered at the Conference for Law Reform Agencies for Eastern and Southern Africa on 'The Role of Law Reform in Constitutionalism, Rule of Law and Democratic Governance', Lilongwe, Malawi, 7-11.11.2011.

${ }^{106}$ V. Reding 'The EU and the Rule of Law - What next?', European Commission 2013 - SPEECH/13/677. 
horde of extremist Huns from Budapest ruining the liberal foundations of the Union, has little or no grounding in fact. ${ }^{107}$ Certainly it is not my intention to belittle any possible violation of the international rule of law in the relevant case: one may argue that the dismantlement of the SADC Tribunal at least amounted to a violation of legitimate expectations on the part of individuals subjected to the jurisdiction of the SADC's state parties, as to an efficient treaty-based remedy to human rights violations ${ }^{108}$. However, at the same time, an acceptance of the EAC Court's expanding jurisdiction counterweights to some extent the SADC's failure and heralds African states' willingness to adhere to the international rule of law contradicting, at least partly, any unconditional suggestions to the contrary. It should be stressed furthermore that the legality of the particular SADC Summit decision regarding the SADC Tribunal is far from being a clearcut issue. Having rendered the SADC Tribunal un-operational pursuant to a unanimous decision of all SADC state parties appears to represent a permissible contractual departure from what was laid down in the SADCT and its Protocol, during the course of subsequent conduct regarding their application ${ }^{109}$.

107 J. Cornides 'The European Union: Rule of Law or Rule of Judges?' 11.11.2013 http://www.ejiltalk.org/the-european-union-rule-of-law-or-rule-of-judges/\#more-9828 (accessed 30.11.2013).

108 African Commission decided that neither the right to fair trial nor independence of courts were violated by SADC Member States, see: African Commission, Luke Munyandu Tembani and Benjamin John Freeth (represented by Norman Tjombe) v. Angola and Thirteen Others, No. 409/12, Decision of 30.4.2014.

${ }_{109}$ Case concerning the interpretation of the air transport services agreement between the United States of America and France The Arbitration Tribunal (22.12.1963) XVI RIAA, pp. 62-63; Legal consequences for states of the continued presence of South Africa in Namibia (South West Africa) notwithstanding Security Council resolution 276 (1970), ICJ (21.6.1971), ICJ Reports, p. 16, para 22; M.G. Kohen, Keeping Subsequent Agreements and Practice in Their Right Limits in G. Nolte (ed), Treaties and Subsequent Practice (2013), pp. 34-45. 